D’Hondt, S.L., Jørgensen, B.B., Miller, D.J., et al., 2003

Proceedings of the Ocean Drilling Program, Initial Reports Volume 201

\title{
4. THE USE OF INFRARED THERMAL IMAGING TO IDENTIFY GAS HYDRATE IN SEDIMent Cores'
}

\author{
Kathryn H. Ford, ${ }^{2}$ Thomas H. Naehr, ${ }^{3}$ C. Gregory Skilbeck, and \\ the Leg 201 Scientific Party ${ }^{5}$
}

\begin{abstract}
An infrared thermal imaging camera was used to image sediment cores on the catwalk, immediately following coring and prior to processing. The camera was used to identify negative temperature anomalies. These were investigated for their utility in identifying gas hydrate prior to dissociation, which occurs rapidly because of the temperature increase and pressure decrease associated with the coring process. The camera was successful in identifying distinct negative temperature anomalies in intervals of gas hydrate. The methodology requires some modification to improve efficiency but holds great potential to investigate thermal properties of sediments and rapidly identify gas hydrate.
\end{abstract}

\section{INTRODUCTION}

The identification of gas hydrate in sediment cores is of great interest for the study of hydrate distribution in sedimentary sequences, as well as for the detection and sampling of individual gas hydrate occurrences after core recovery. Since hydrate is stable only in high-pressure and low-temperature environments, it dissociates rapidly as cores undergo depressurization and heating during wireline recovery. As this dissociation is an endothermic process, sediment containing hydrate is cooled relative to the surrounding sediment, thus creating a negative temperature anomaly. Previously employed methods for the identification of this thermal anomaly included tactile methods and the use of ther-
'Ford, K.H., Naehr, T.H., Skilbeck, C.G., and the Leg 201 Scientific Party, 2003. The use of infrared thermal imaging to identify gas hydrate in sediment cores. In D'Hondt, S.L., Jørgensen, B.B., Miller, D.J., et al. (Eds.), Proc. ODP, Init. Repts., 201, 1-20 [Online]. Available from World Wide Web: <http://www-odp.tamu.edu/ publications/201_IR/VOLUME/ CHAPTERS/IR201_04.PDF>, [Cited YYYY-MM-DD].

${ }^{2}$ Graduate School of Oceanography, University of Rhode Island, South Ferry Road, Narragansett RI 02882, USA.khford@gso.uri.edu ${ }^{3}$ Department of Physical and Life Sciences, Texas A\&M UniversityCorpus Christi, 6300 Ocean Drive, Corpus Christi TX 78412, USA. ${ }^{4}$ Department of Environmental Sciences, University of Technology, Sydney, 1 Broadway, Sydney NSW 2007, Australia.

${ }^{5}$ Shipboard Scientific Party addresses.

Ms 201IR-104 


\section{K.H. Ford et Al.

mistor arrays (Paull, Matsumoto, Wallace, et al., 1996). However, tactile methods are nonquantitative and thermistor arrays do not provide rapid continuous records of entire cores. Therefore, an infrared (IR) thermal imaging camera was introduced during Leg 201 to scan core liners for thermal anomalies immediately after core recovery.

Infrared radiation $(\sim 0.750-350 \mu \mathrm{m})$ is emitted by all objects as a function of their temperature. As the temperature of an object decreases, the wavelength of maximum emission increases. For hydrate, longwave infrared $(8-12 \mu \mathrm{m})$ is the focus. The amount of thermal radiation emitted by an object is dependent upon the emissivity and temperature of the object (Stefan-Boltzmann Law). Emissivity is basically an efficiency factor. An object with an emissivity of 1 is a very efficient energy emitter (or absorber) and is known as a blackbody. In addition to emitting, an object can also reflect or transmit infrared radiation. Kirchhoff's Law states that the total infrared radiation leaving the surface of an object is a combination of emitted radiation (from the object itself), reflected radiation (the object reflects infrared radiation from another source), and transmitted radiation (the amount of infrared radiation coming through the object from another source). For example, a perfect infrared mirror would have an emissivity and transmissivity of 0 . In contrast, a perfect infrared window would have an emissivity and reflectivity of 0 . For examining relative temperatures, it is important to maintain the same values for these characteristics for each analysis. When examining absolute temperatures, determining the emissivity, transmissivity, and reflectivity of an object is critical. Establishing these parameters was the first step in the development of the infrared camera core scan method. The impact of air temperatures and scanning operators was studied to ensure that time of day or slightly different scanning methods did not impact measured core liner temperatures.

The ultimate goal was to establish a procedure with which hydrate could be identified in cores on the catwalk as quickly and reliably as possible. Toward that end, results from nonhydrate-bearing cores and hydrate bearing cores are presented.

\section{METHODS}

The camera used during Leg 201 was a ThermaCam SC 2000 camera, made by FLIR Systems. This camera measures temperatures from $-40^{\circ} \mathrm{C}$ to $+1500^{\circ} \mathrm{C}$. For onboard application, it was set to record a range of temperatures from $-40^{\circ} \mathrm{C}$ to $+120^{\circ} \mathrm{C}$ (range 1). The precision of this camera is $0.1^{\circ} \mathrm{C}$ at $30^{\circ} \mathrm{C}$ and the accuracy is $\pm 2^{\circ} \mathrm{C}$. However, emissivity corrections can improve the accuracy to $0.0^{\circ} \mathrm{C}$ (R. Rogers, pers. comm., 2002 [N1]).

In order to achieve the most accurate temperature measurements, the emissivity of the core liner was established by placing a piece of electrical tape (with a known emissivity of 0.95 ) on the core liner. The apparent temperatures of the tape and the core liner were compared, and the emissivity of the core liner was determined to be 0.95 (tape was not visible on the core liner with the IR camera). Polycarbonate tubing is opaque to infrared radiation, so the remaining radiation was attributed to reflection. All analyses were conducted with the emissivity set at 0.95 .

The camera was mounted on a wheeled cart (Fig. F1) to maintain constant distance between the camera and core liner and rolled across each core before any other sampling was conducted on the catwalk. A dedicated lap-top computer recorded the camera images at a rate of 5 frames/s. An external screen attached to the camera showed a range of

F1. Infrared camera, p. 8.

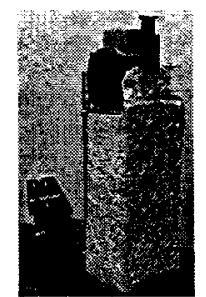


temperatures from $15^{\circ}$ to $25^{\circ} \mathrm{C}$. This allowed immediate identification of cold spots, which were then visually and/or chemically inspected for evidence of hydrate. A depth scale was established in order to correlate the hydrate identified by the camera with other physical properties, chemical properties, and visual observations of hydrate. This was done by assigning the curated depth to the first image, then dividing the total core length by the number of images. Then a depth was incrementally assigned to each image. There were typically 200-300 images for each core. The images were analyzed with FLIR ThermaCam Researcher software. An analysis box was hand selected in the first image of the sequence file and was placed to avoid areas of significant reflection or other interference. The sequence file was played from beginning to end, and the maximum, minimum, and average temperatures from the analysis box were extracted from each image. All temperatures presented are minimum temperatures to highlight negative temperature anomalies. Further details of camera setup and data analysis procedures are available in "Infrared Thermal Imaging," p. 42, in "Physical Properties" in the "Explanatory Notes" chapter.

Scans at Sites 1226 and 1230 were used for comparison between a nonhydrate-bearing site and a hydrate-bearing site, respectively.

\section{Air Temperatures}

Air temperature data were recorded by the officers of the ship's bridge every $4 \mathrm{hr}$. The thermometer was located in a weather box adjacent to the bridge, $\sim 50 \mathrm{ft}$ away from the catwalk where the cores were imaged.

\section{RESULTS AND DISCUSSION}

\section{Air Temperatures vs. Core Liner Temperatures}

The air temperature taken at the bridge closest to the time the core was on deck was compared to the average core liner temperature for the core (Fig. F2). In addition, comparisons of day and night and camera operators (noon to midnight vs. midnight to noon watches) were conducted to determine a possible sampling bias (Fig. F3). No correlations were found. Core liner temperatures from top to bottom of the $10-\mathrm{m}$ cores were examined to investigate any effect (particularly warming) associated with the method of scanning or the time elapsed during the scan ( $\sim \mathrm{min})$. Ten scans (five each from Sites 1226 and 1230) were randomly selected and compared. No consistent warming of the cores was observed (Fig. F4).

\section{Hydrate Identification}

The first independent evidence of gas hydrate at Site 1230 was visual observation of fizzing sediment (small white bubbles) interpreted to be decomposing hydrate in Section 201-1230A-15H-5; 123.5 meters below sea floor (mbsf). A subsequent review of the IR scan for that core revealed that core liner temperatures of the fizzing section were only a few degrees cooler (average $=4^{\circ} \mathrm{C}$ cooler) than the surrounding sediment (Table T1). Based on this observation, camera span and level were set so that the $15^{\circ}$ to $25^{\circ} \mathrm{C}$ range was visible, which simplified the subsequent identification of cold spots caused by gas hydrate dissociation.
F2. Air temperatures compared to core liner temperatures, p. 9.
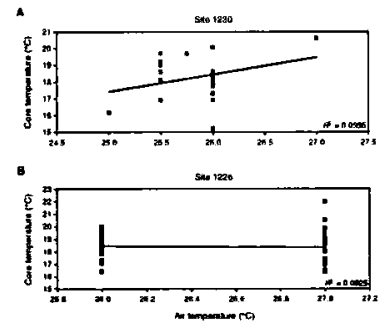

F3. Time of day and watch compared to core liner temperatures, p. 10.

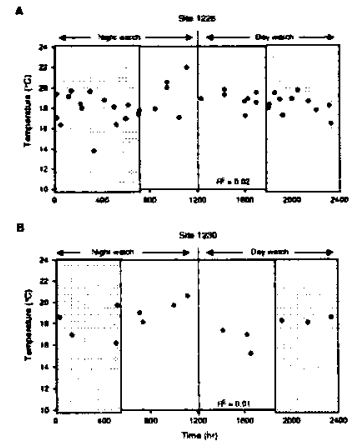

F4. Core liner temperatures for five cores, p. 11.

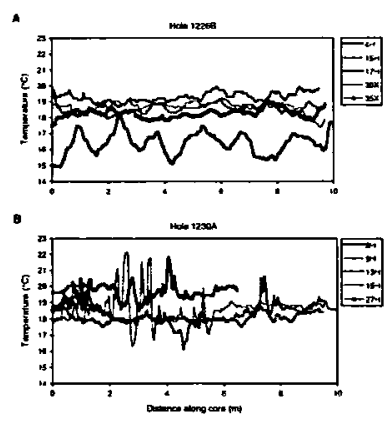

T1. Core liner temperatures with hydrate and surrounding sediments, p. 18. 
Cold spots were first identified with the camera and then visually confirmed to be hydrate nodules or fizzing sediment in Cores 201-1230A$26 \mathrm{H}$ and $1230 \mathrm{~B}-12 \mathrm{H}$. Figure F5 illustrates the thermal contrast between an interval of fizzing sediment and the surrounding sediment.

A thorough examination of the downcore temperature plots revealed a greater variability in cores with hydrate nodules or fizzing sediment. Figure F6 illustrates the difference between cores that did not contain hydrate and cores that did contain hydrate or fizzing sediment. The standard deviation of the minimum temperatures in hydrate-bearing cores are generally $>1^{\circ} \mathrm{C}$, whereas in nonhydrate-bearing cores it is usually $<1^{\circ} \mathrm{C}$ (Table $\mathrm{T} 2$ ). This can be explained by the contrast between low temperatures in the hydrate-bearing sediments and high temperatures typical of associated gas expansion voids (voids warm to ambient temperatures rapidly). This is not a fixed rule, however, and emphasizes the current need for careful core-by-core interpretation of both the thermal plots and the original image files. Although visual confirmation of hydrate is necessary for positive identification, careful analysis of the downcore temperature plots and thermal images suggest other hydrate occurrences at Site 1230 in Cores 201-1230A-11H, 13H, 21H, and 35X and 201-1230B-11H (Figure F7; see also "Appendix," p. 7). Hopefully, developments will be made in the future to normalize core temperatures for the wireline trip, allowing confirmation of in situ temperatures and presence of hydrate using thermal imaging data alone.

\section{Comparison with Other Physical Property Measurements}

To conduct a comparison of the thermal data with other physical property measurements, composite downhole plots were generated. The curated depths of the two hydrate nodule occurrences and three intervals of fizzing sediment observed at Site 1230 were compared to the depths assigned based on the thermal image analyses (Table T1). Although imperfect, the two depth scales are comparable, suggesting that the thermal image depths may be useful for the generation of composite downhole plots.

Resistivity, $P$-wave velocity, natural gamma ray (NGR) emission, and core liner temperature all illustrate increasing variability between $\sim 80$ and 165 mbsf (Fig. F8). The dissociation of hydrate with increased temperature and decreased pressure alters the core by altering the water content of surrounding sediments and creates gas expansion voids. This results in depth discrepancies between downhole log (wireline) data and shipboard measurements. However, although centimeter-scale correlation is not yet feasible, zones of identified and potential hydrate occurrence are recognizable. These correlations are more fully investigated in "Physical Properties," p. 22, in the "Site 1230" chapter. Interestingly, the thermal data from Site 1226 also show a correlation with other physical property measurements (Fig. F9). This could be explained by differential warming of distinct lithologies during wireline recovery.

\section{PROBLEMS AND FUTURE WORK}

Although we have shown that the IR camera can be a valuable tool for rapid gas hydrate identification, there are several issues that need to
F5. Thermal contrast between hydrate and surrounding sediment, p. 12.

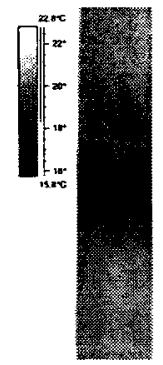

F6. Temperatures of cores without and with hydrate, p. 13.

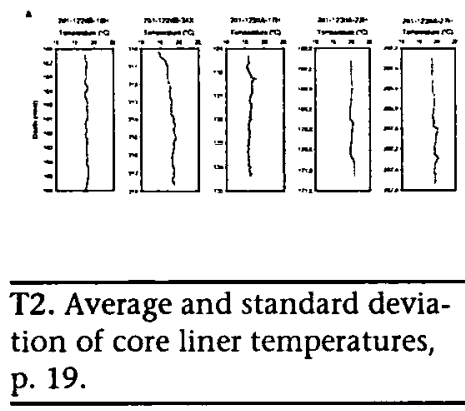

F7. Thermal signatures suggestive of hydrate, p. 15.

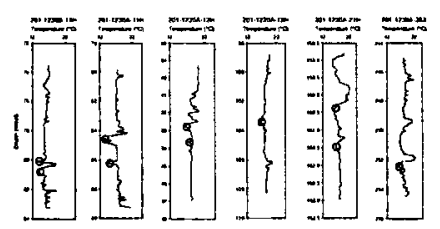

F8. Comparison of thermal data with physical property measurements, Hole 1230 A, p. 16.

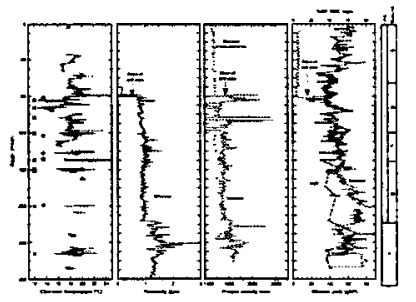


K.H. FORD ET AL.

be addressed in order to make the transition from a mainly qualitative tool to a more quantitative method.

1. Core handling times and catwalk temperature need to be monitored more carefully than was possible during Leg 201. The times to be measured include the wireline trip time and the time it takes to extract the core liner from the barrel, move it to the catwalk, and run the thermal scan. Whereas we have illustrated that scan times did not affect the core liner temperature distribution, the wireline trip does, and it has been suggested that core handling procedures can significantly affect the core temperatures (M. Storms and T. Bronk, unpubl. data [N2]). This is particularly important for hydrate and microbiological sampling, which are very temperature sensitive. Additionally, examining air temperatures at the time of scanning (rather than depending on the bridge's 4-hr measurements) would conclusively confirm a lack of sampling bias associated with air temperature.

2. A track is needed to run the camera along the core at constant speed. This will greatly facilitate depth calculation and correlation of the temperature data to other physical property data. The use of a track might also reduce problems with focusing and with reflections caused by the curvature of the core liner. If the camera were run across the core at a constant angle relative to the core, possible reflections would at least remain constant as well.

3. The use of the image analysis software needs to be standardized to avoid user-dependent biases during data analysis. It is also integral to increase the efficiency of the analyses.

4. Emissivity differences of different sediment types need to be taken into consideration. This will be especially important for temperature scans of split-core surfaces to examine hydrate distribution, since emissivity differences of various sediment types will significantly influence the absolute temperature readings of the camera.

Despite the need for improvement, thermal imaging has proven to be a successful method for gas hydrate identification in sediment cores. This method has great potential for becoming a valuable tool for gas hydrate identification and quantification in the future.

\section{ACKNOWLEDGMENTS}

The authors would like to acknowledge Glen Gettemy, Steve D'Hondt, and the rest of the Leg 201 Shipboard Scientific Party for useful discussions and help in the development of this method. We would also like to thank Kim Bracchi and Steve Tran for many long hours setting up and running the camera. Special thanks to Frank Rack for providing the camera and essential precruise training. The paper also benefited from the input of Jay Miller, Gerardo Iturrino, and an anonymous reviewer.

This research used samples and data provided by the Ocean Drilling Program (ODP). The ODP is sponsored by the U.S. National Science Foundation (NSF) and participating countries under management of Joint Oceanographic Institutions (JOI), Inc.
F9. Comparison of thermal data with MST measurements, Hole 1226B, p. 17.

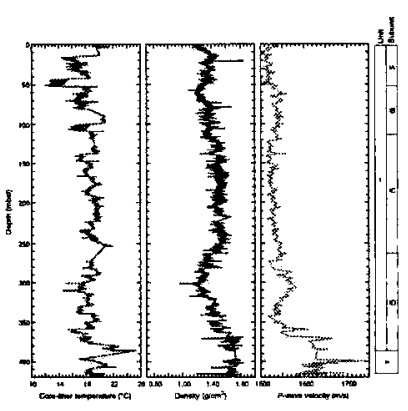


K.H. FORD ET AL.

Chapter 4, INFraRed Thermal IMAgING

REFERENCES

Paull, C.K., Matsumoto, R., Wallace, P.J., et al., 1996. Proc. ODP Init. Repts. 164: College Station, TX (Ocean Drilling Program). 
K.H. FORd ET AL.

ChAPTER 4, INFRARED ThERMAL IMAgING

APPENDIX

Specific Depths of Known and Hypothesized Hydrate Occurrences

\begin{tabular}{|c|c|c|c|}
\hline $\begin{array}{l}\text { Core, } \\
\text { section }\end{array}$ & $\begin{array}{l}\text { Top of } \\
\text { sample depth } \\
\text { (mbsf) }\end{array}$ & $\begin{array}{l}\text { IR camera } \\
\text { depth } \\
\text { (mbsf) }\end{array}$ & Comments \\
\hline \multicolumn{4}{|c|}{ 201-1230B- } \\
\hline $11 \mathrm{H}$ & & 80.08 & \\
\hline $11 \mathrm{H}$ & & 80.80 & \\
\hline $12 \mathrm{H}-2$ & 81.54 & 81.76 & Foliated hydrate nodule \\
\hline $12 \mathrm{H}$ & & 82.38 & \\
\hline \multicolumn{4}{|c|}{ 201-1230A- } \\
\hline $11 \mathrm{H}$ & & 84.41 & \\
\hline \multicolumn{4}{|c|}{ 201-1230B- } \\
\hline $12 \mathrm{H}$ & & 85.31 & \\
\hline $12 \mathrm{H}$ & & 86.62 & \\
\hline $12 \mathrm{H}$ & & 88.58 & \\
\hline \multicolumn{4}{|c|}{$201-1230 \mathrm{~A}-$} \\
\hline $12 \mathrm{H}$ & & 92.74 & \\
\hline $13 \mathrm{H}$ & & 103.35 & \\
\hline $15 \mathrm{H}$ & & 120.55 & \\
\hline $15 \mathrm{H}$ & & 121.34 & \\
\hline $15 \mathrm{H}-5$ & 123.47 & 123.37 & Fizzing sediment \\
\hline $18 \mathrm{H}-3$ & 141.80 & 141.90 & Fizzing sediment \\
\hline $19 \mathrm{H}-1$ & 148.30 & 148.57 & Hydrate nodule \\
\hline $19 \mathrm{H}$ & & 149.32 & \\
\hline $19 \mathrm{H}$ & & 149.70 & \\
\hline $19 \mathrm{H}$ & & 150.00 & \\
\hline $21 \mathrm{H}$ & & 158.93 & \\
\hline $21 \mathrm{H}$ & & 160.36 & \\
\hline $21 \mathrm{H}$ & & 161.42 & \\
\hline $26 \mathrm{H}-2$ & 199.91 & 199.58 & Fizzing sediment \\
\hline $26 \mathrm{H}$ & & 200.10 & \\
\hline $35 x$ & & 252.38 & \\
\hline
\end{tabular}

Note: IR = infrared. 
K.H. FORD ET AL.

Chapter 4, INFRARED Thermal IMAgING

Figure F1. Infrared camera on wheeled cart for rolling down cores on catwalk prior to other sampling. A cardboard box was extended from the lens to the core liner and covered with reflective aluminum foil to shield external infrared radiation from the core.

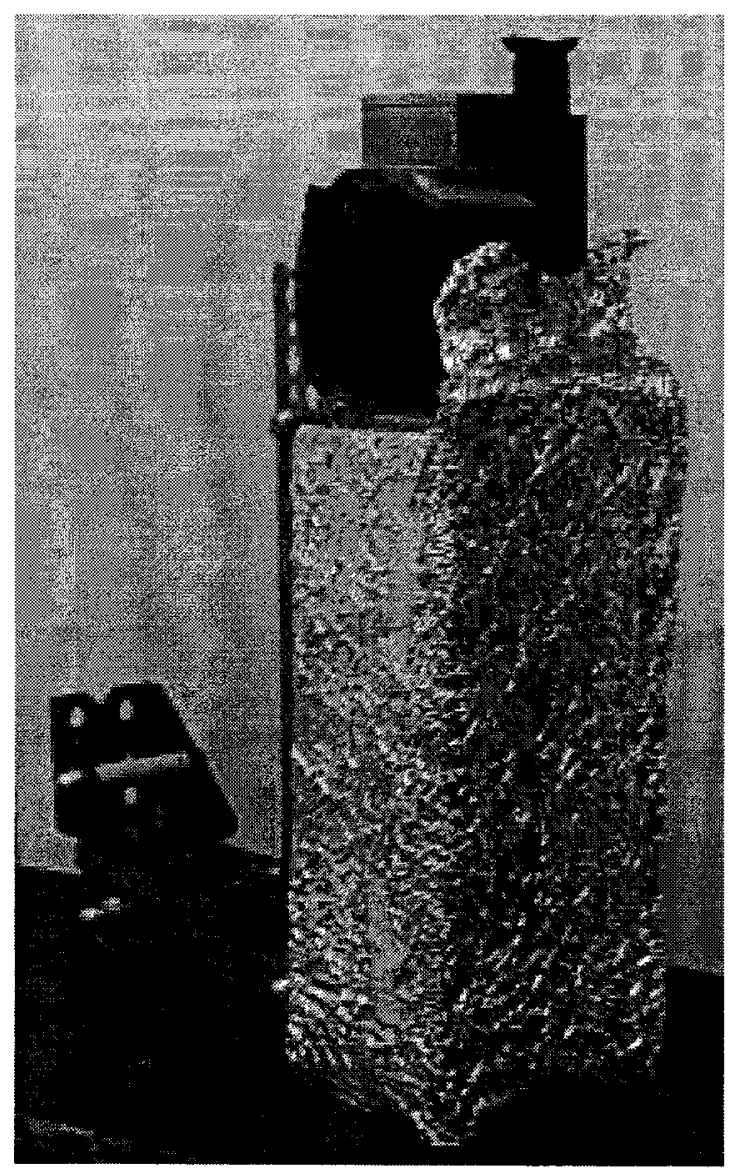


K.H. Ford et al.

Chapter 4, INFrared Thermal IMaging

Figure F2. Air temperatures compared to core liner average temperatures. A. Site 1226. B. Site 1230. No sampling bias was found.

A

Site 1230

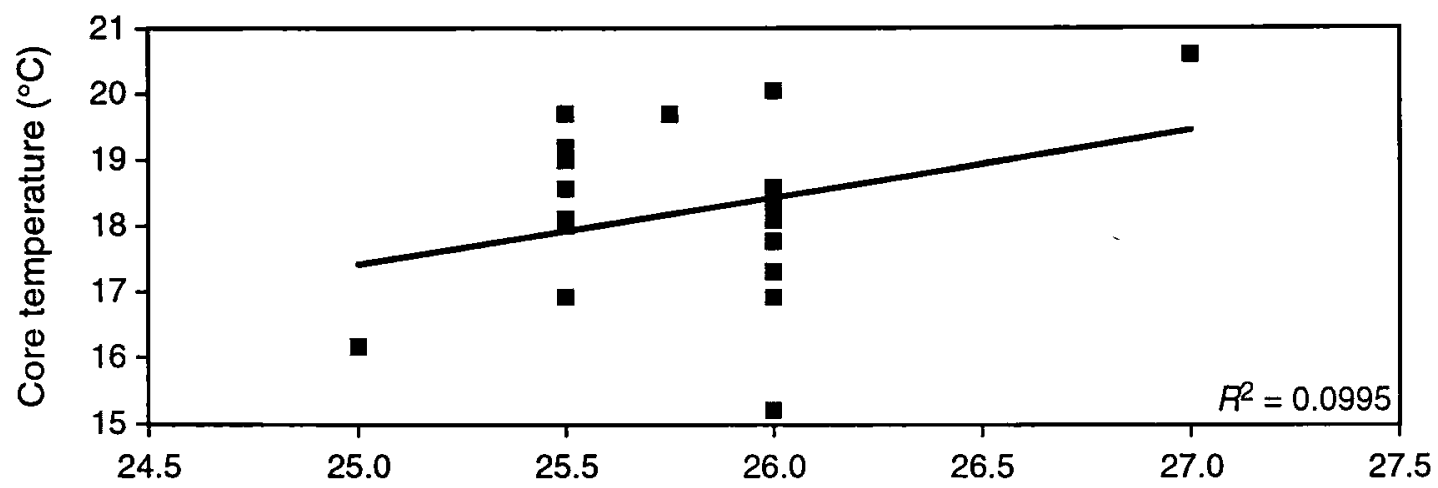

B

Site 1226

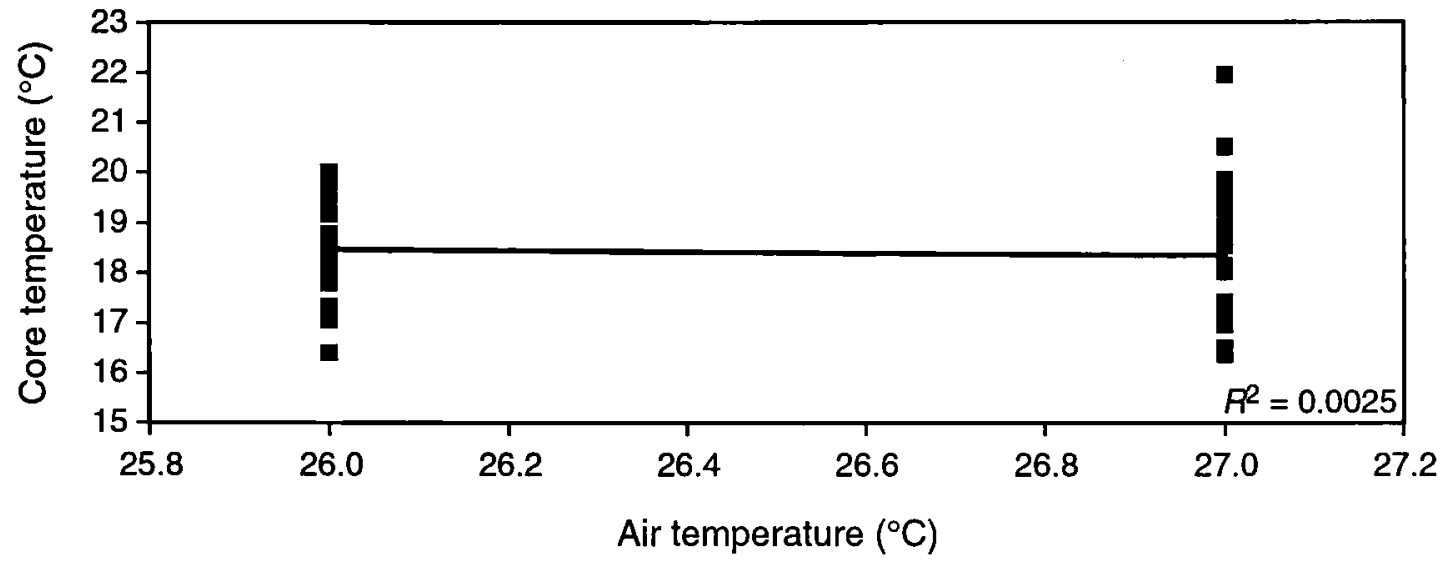


K.H. FORD ET AL.

Chapter 4, INFrared Thermal IMaging

Figure F3. Time of day and watch compared to core liner average temperatures. Nighttime (1800-0700 hr) is shaded. Night watch and day watch are indicated at the top and divided with the dotted line. A. Site 1226. Average daytime core temperature $=18.73^{\circ} \pm 1.26^{\circ} \mathrm{C}$, and average nighttime core temperature $=$ $18.05^{\circ} \pm 1.47^{\circ} \mathrm{C}$. Average day watch core temperature $=18.50^{\circ} \pm 0.93^{\circ} \mathrm{C}$, and average night watch core temperature $=18.28^{\circ} \pm 1.76^{\circ} \mathrm{C}$. B. Site 1230 . Average daytime core temperature $=18.22^{\circ} \pm 1.46^{\circ} \mathrm{C}$, and average nighttime core temperature $=18.29^{\circ} \pm 1.15^{\circ} \mathrm{C}$. Average day watch core temperature $=17.88^{\circ} \pm 1.26^{\circ} \mathrm{C}$, and average night watch core temperature $=18.59^{\circ} \pm 1.28^{\circ} \mathrm{C}$. No sampling bias was found.

A

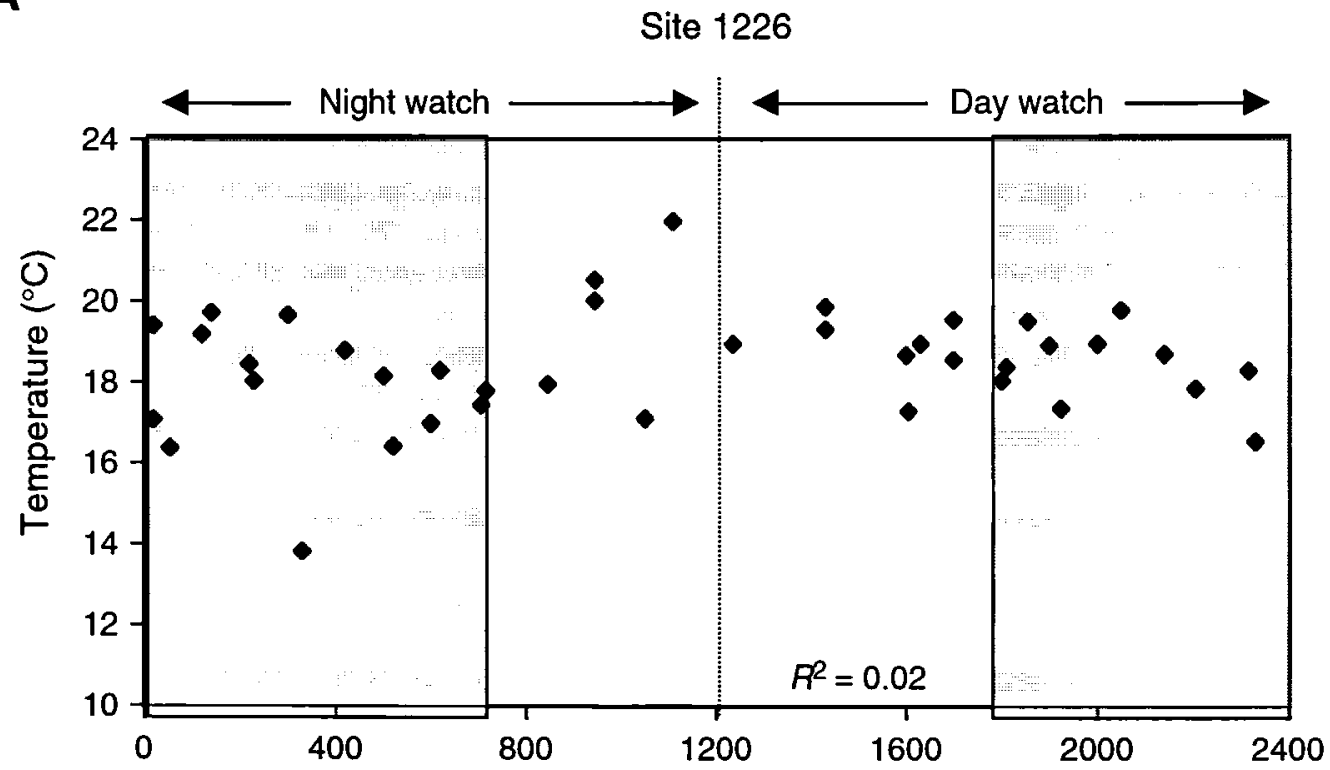

B

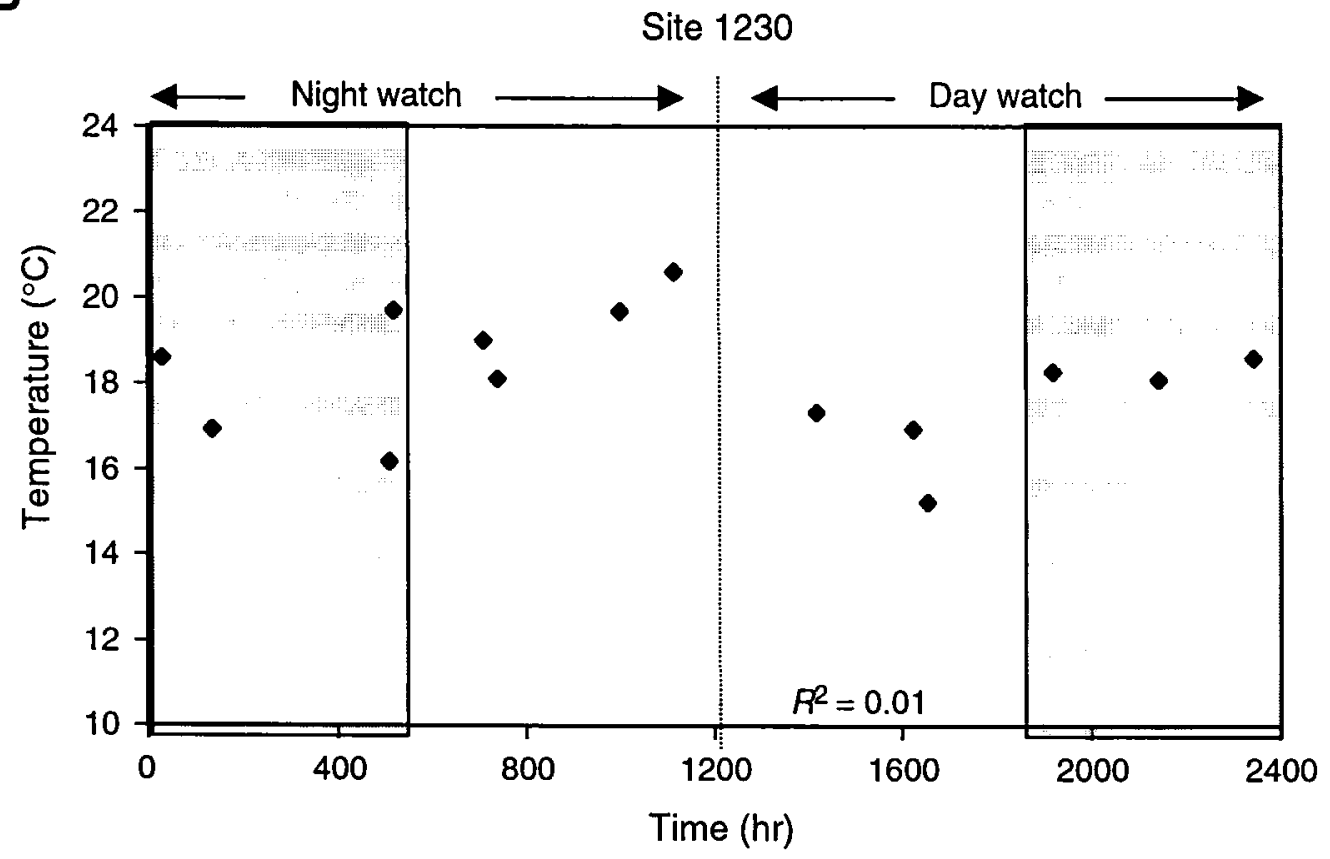


K.H. FORD ET AL.

Chapter 4, INFrared Thermal IMAgIng

Figure F4. Trends in core liner temperatures for five randomly selected cores from (A) Site 1226 and (B) Site 1230. $R^{2}$ values for Site 1226 range from 0.002 to $0.3 . R^{2}$ values for Site 1230 range from 0.01 to 0.5 . No consistent downcore trend is seen. Scan method and time do not have an effect on measured core liner temperatures.

A

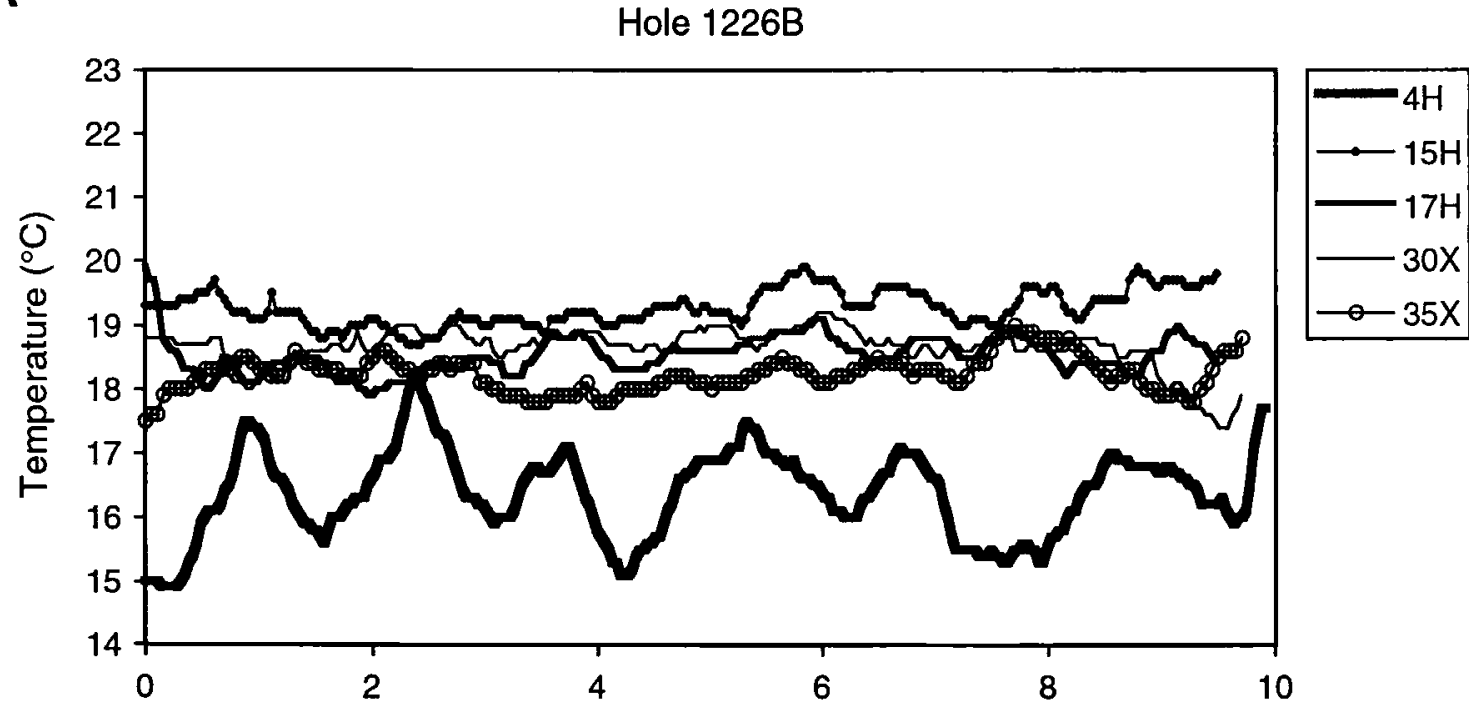

B

Hole 1230A

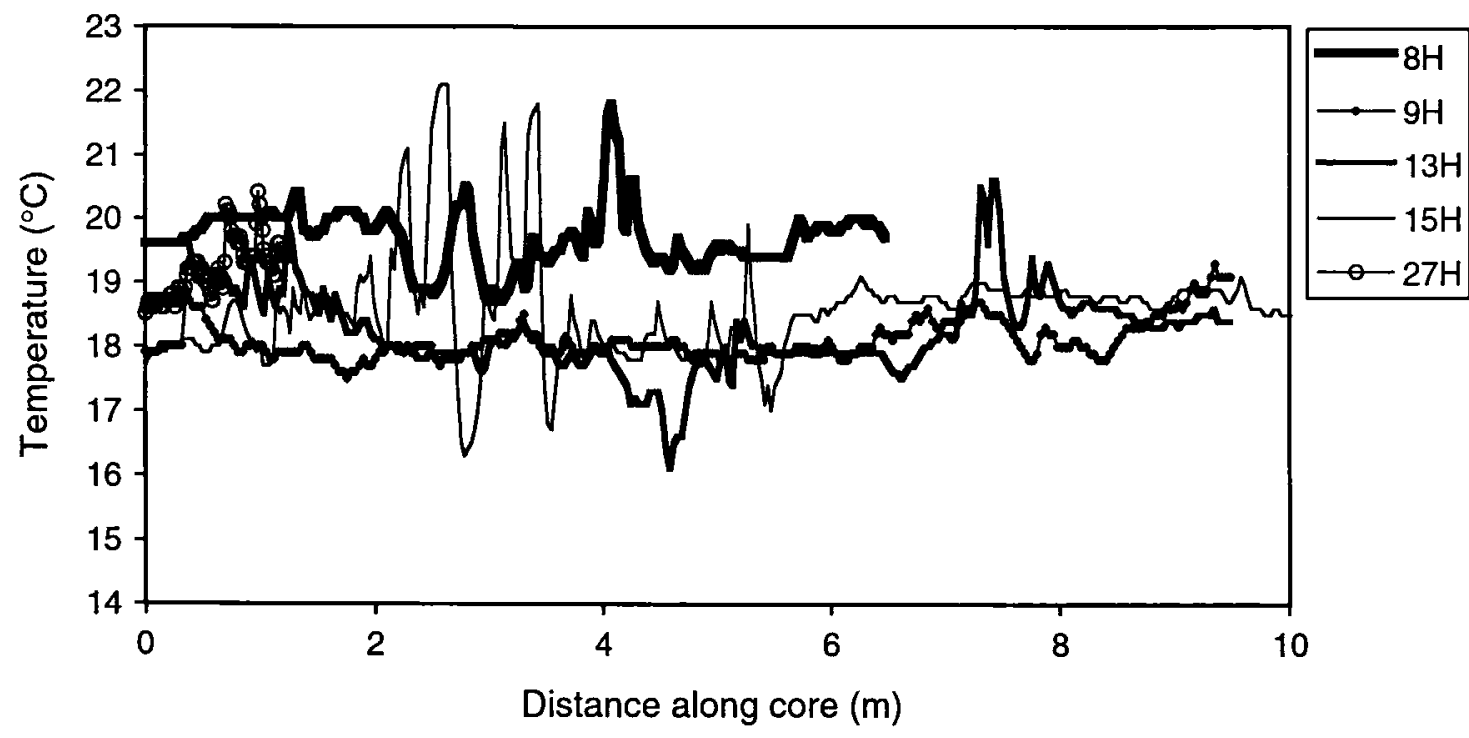


K.H. FORD ET AL.

Chapter 4, INFraRed Thermal IMAgINg

Figure F5. Thermal contrast of core surface between fizzing sediment found in Core $201-1230 \mathrm{~A}-26 \mathrm{H}$ and surrounding sediment. Note the clear visual contrast in image despite $a<4^{\circ} \mathrm{C}$ temperature range. Length of core pictured is $-20 \mathrm{~cm}$.

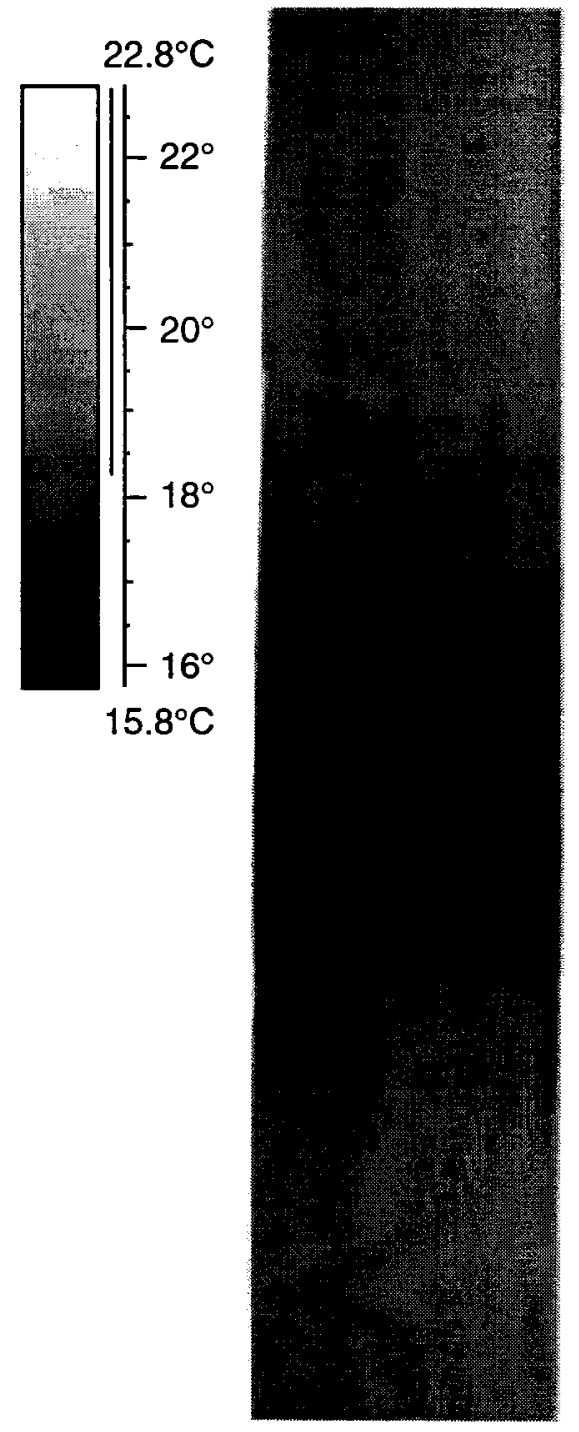


K.H. FORD ET AL.

Chapter 4, INFraRed Thermal IMAgING
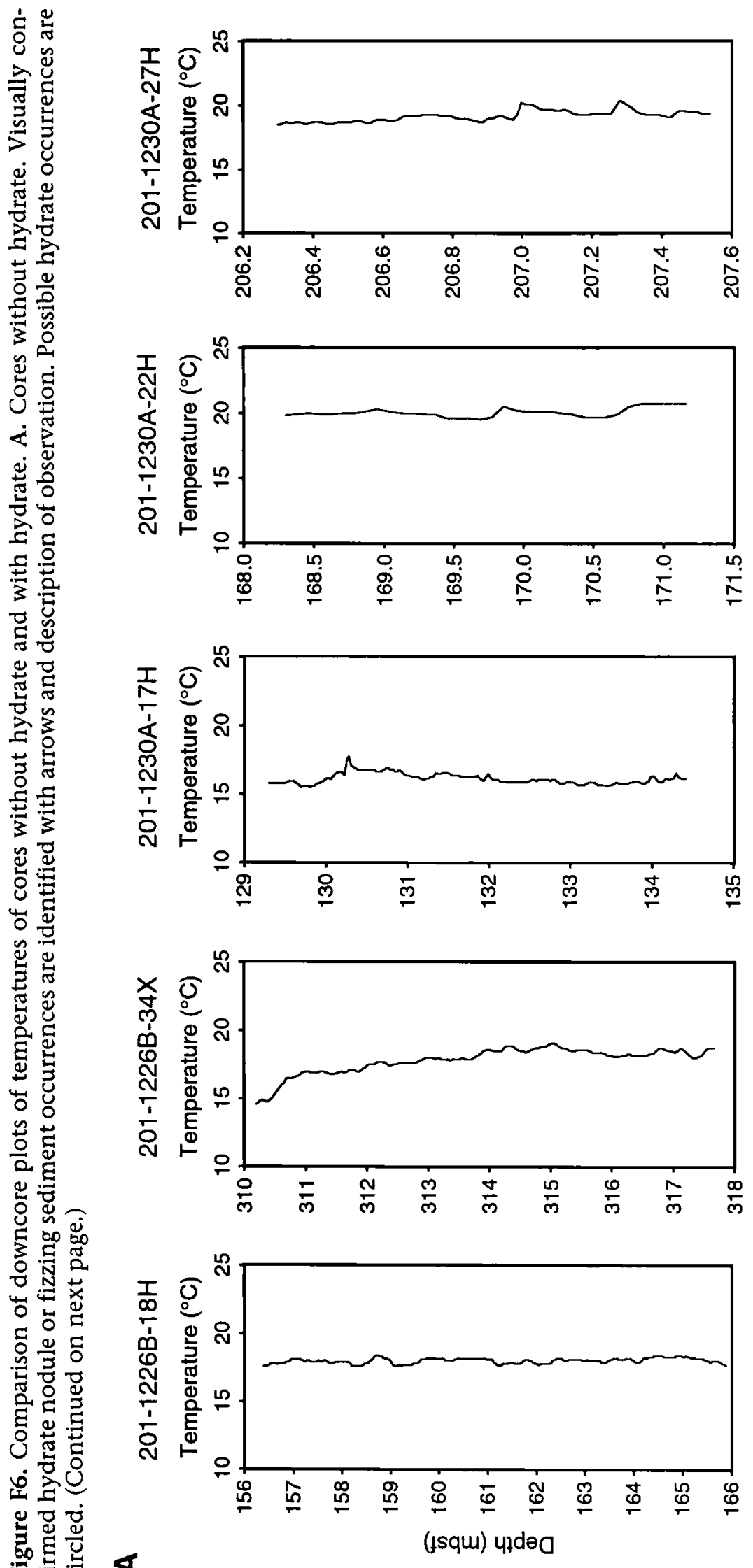

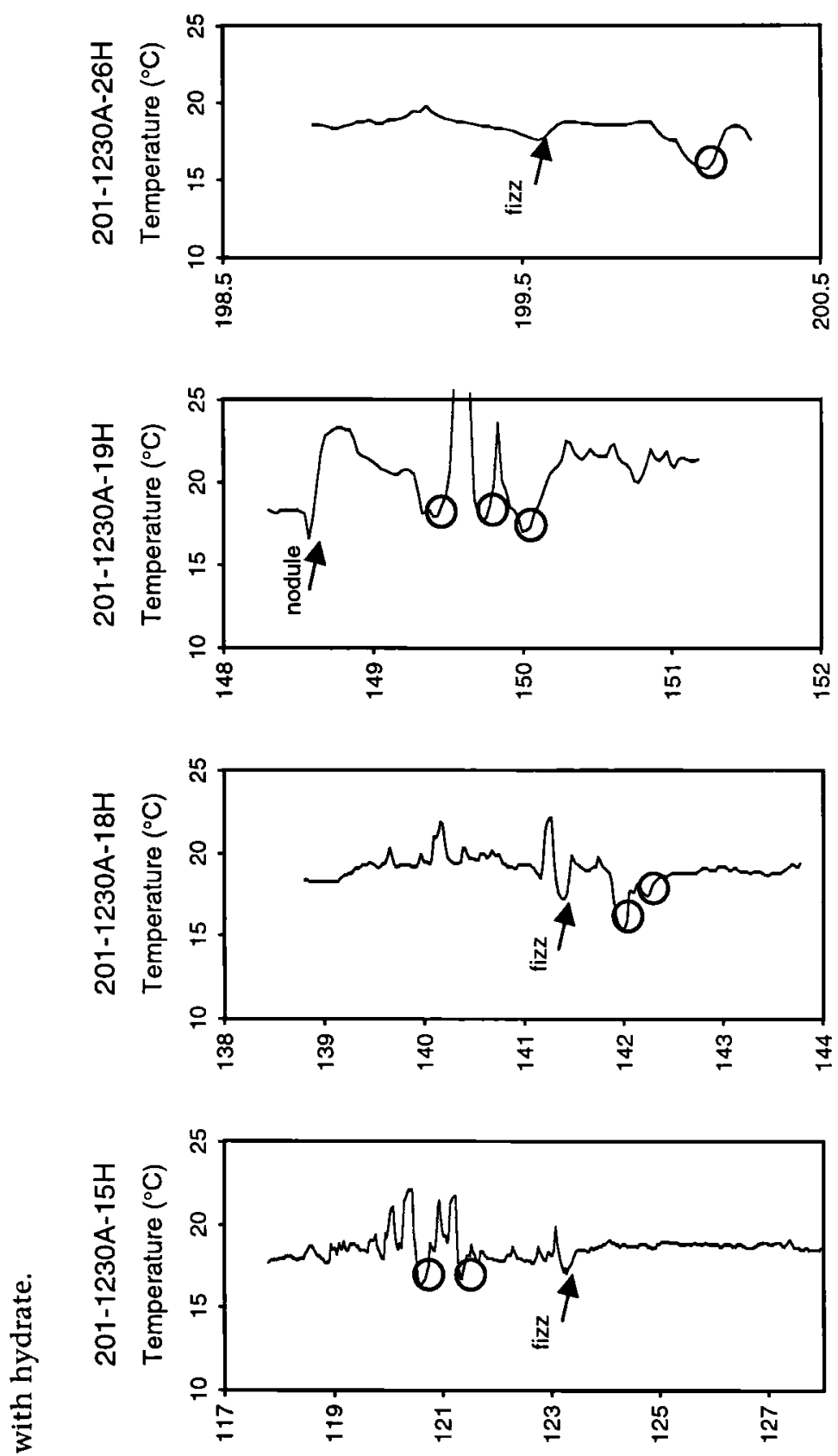

ญ्山

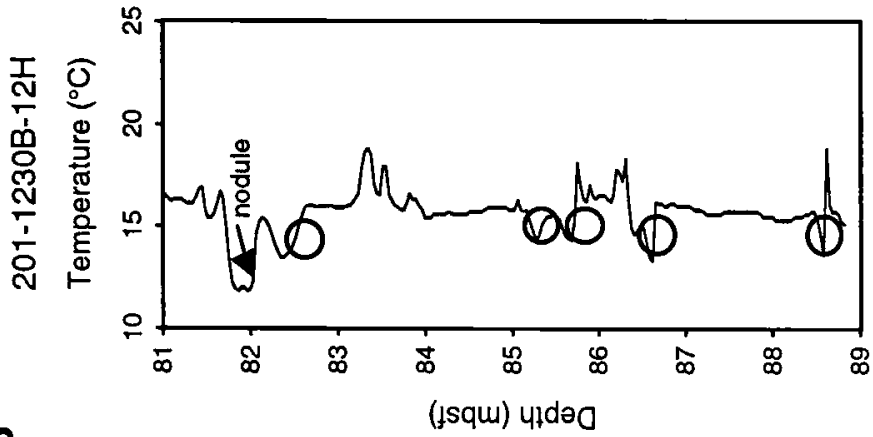

$\mathbf{m}$ 

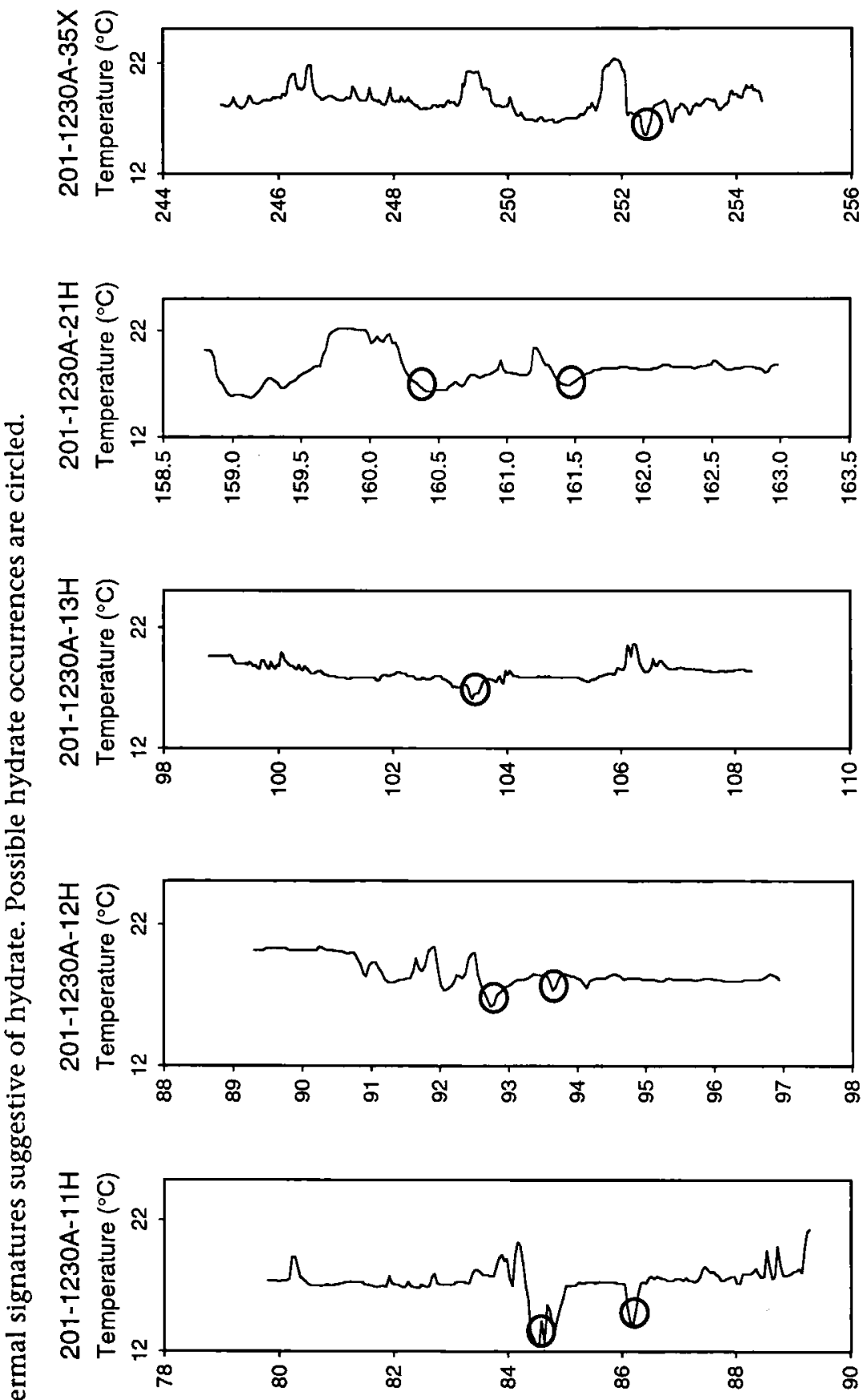

吾

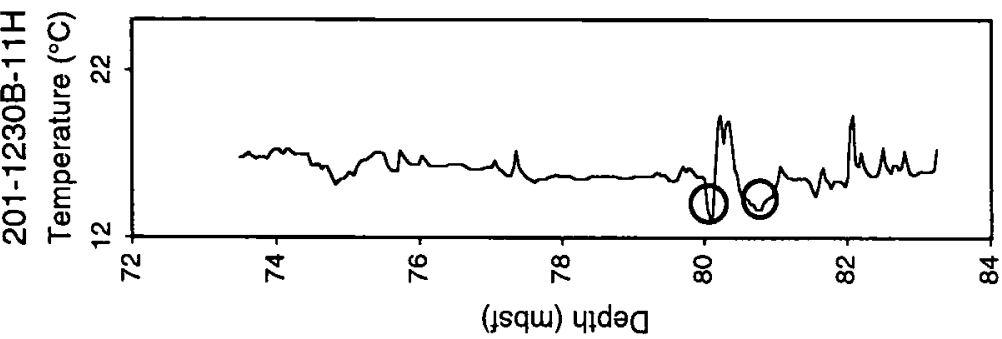


K.H. FORD ET AL.

Chapter 4, INFrared Thermal IMAging

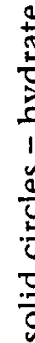



¿

"

응 옹

:

祸

ซु

䨌

II

$+\frac{11}{0}$

$\dot{<}$

กิ

고ำ

옹 혼

它

艺

घ․

帘

$\stackrel{\mathbb{Q}}{\mathscr{E}}$

론동

范

边

름

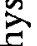

ล.

范

प्मे

吾㞼

ت્ّ

흔

宽

它

岁范

동 Nㅗㅇ

究吉

을

올

$\infty \times$

它

就

50
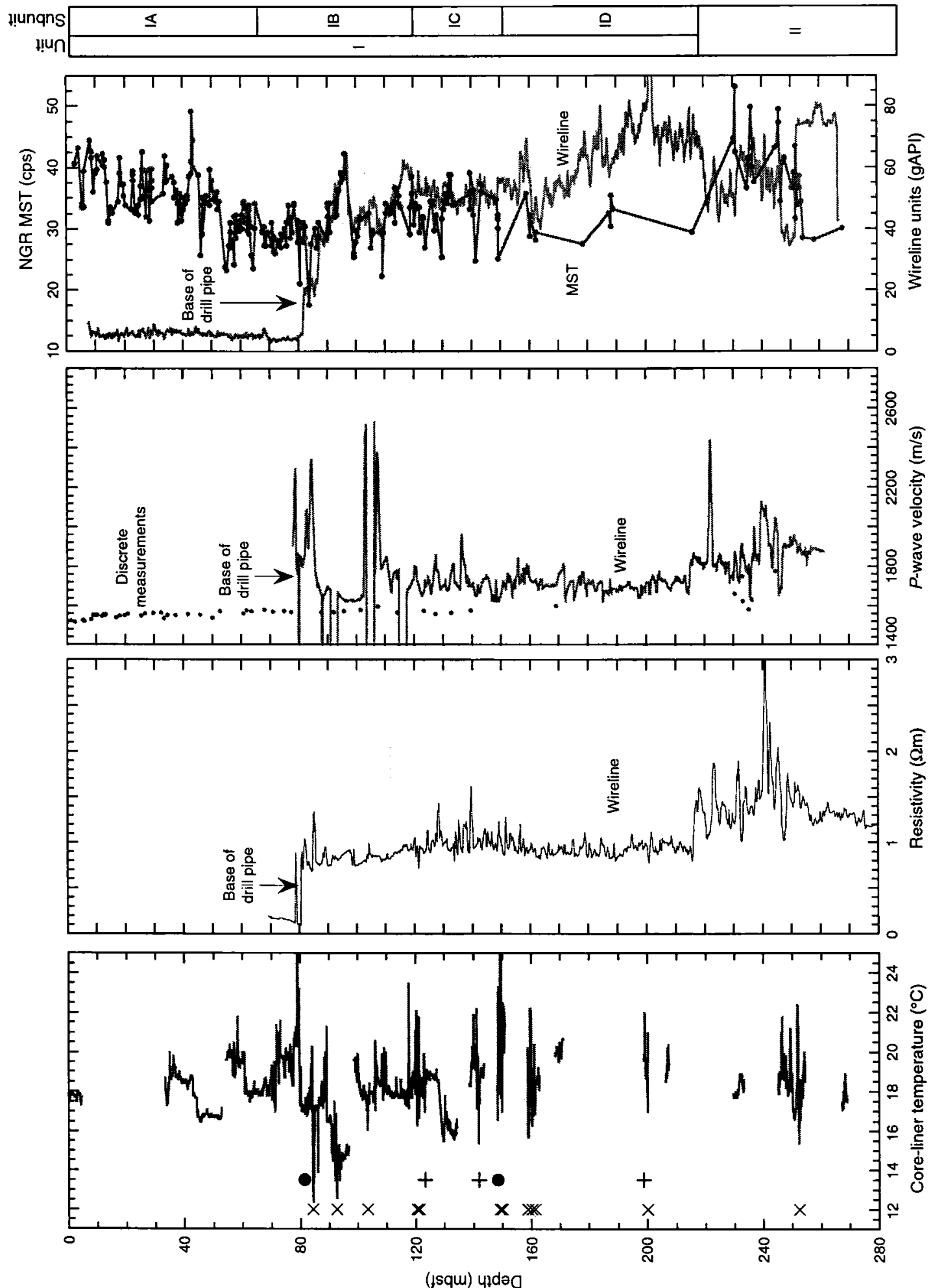
K.H. FORD ET AL.

Chapter 4, Infrared Thermal IMAgING

Figure F9. Comparison of thermal data with multisensor track physical property measurements for Hole 1226B. Similar overall trends are seen and highlighted with shaded regions.

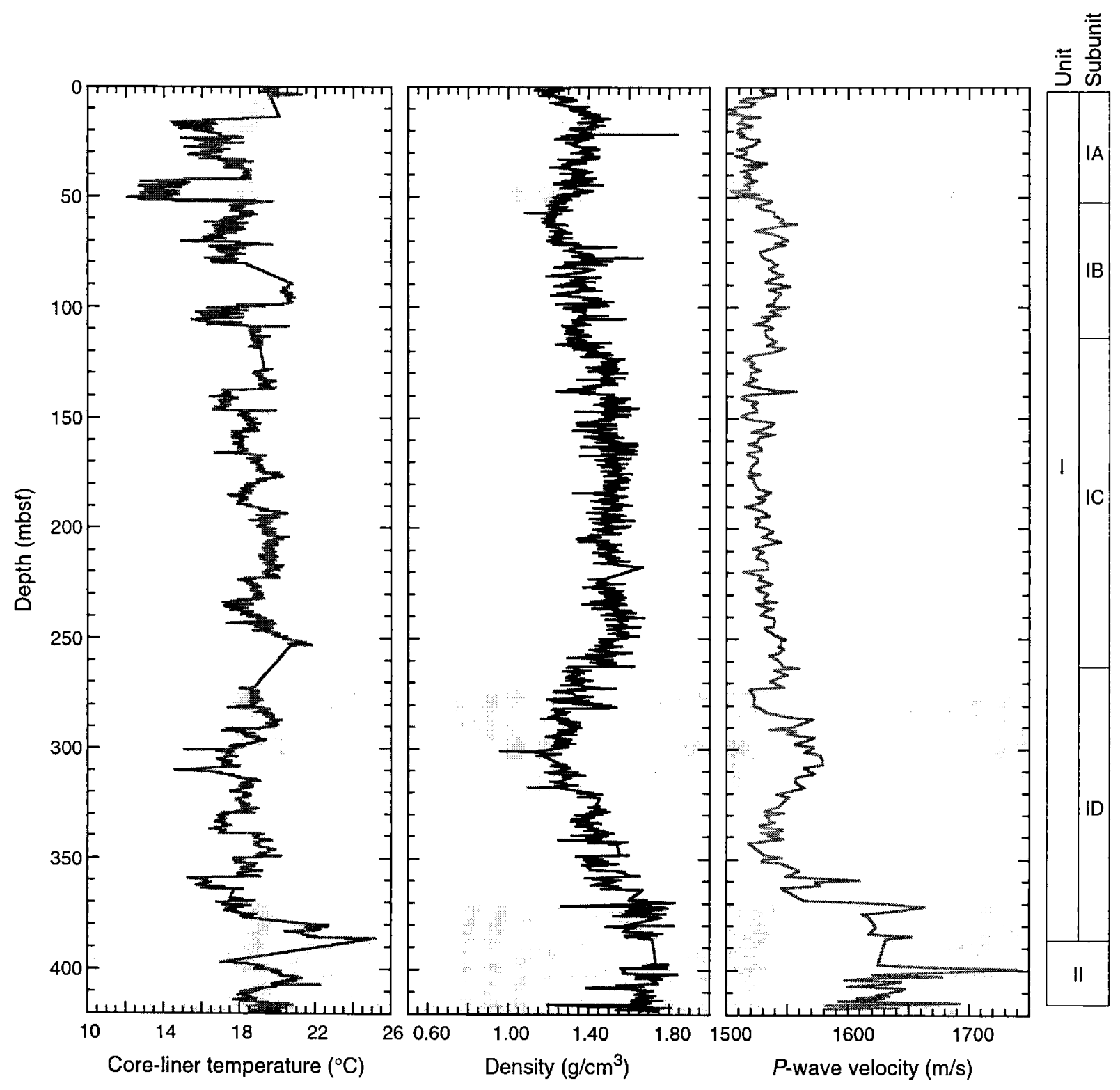


K.H. FORD ET AL.

Chapter 4, INFRARED Thermai IMAging

Table T1. Comparison of core liner temperatures, curated depth, and depth assigned based on infrared thermal image processing for intervals containing hydrate nodules or fizzing sediment.

\begin{tabular}{|c|c|c|c|c|c|c|c|}
\hline $\begin{array}{l}\text { Core, } \\
\text { section }\end{array}$ & Observation & $\begin{array}{l}\text { Core liner } \\
\text { temperature } \\
\left({ }^{\circ} \mathrm{C}\right)^{*}\end{array}$ & $\begin{array}{c}\text { Ambient liner } \\
\text { temperature } \\
\left(^{\circ} \mathrm{C}\right)^{i}\end{array}$ & $\begin{array}{c}\Delta T \\
\left({ }^{\circ} \mathrm{C}\right)\end{array}$ & $\begin{array}{l}\text { Depth } \\
\text { (mbsf) }\end{array}$ & $\begin{array}{l}\text { IR camera } \\
\text { depth } \\
\text { (mbsf) }\end{array}$ & $\begin{array}{c}\Delta \text { Depth } \\
\text { (cm) }\end{array}$ \\
\hline \multicolumn{8}{|c|}{ 201-1230B- } \\
\hline $12 \mathrm{H}-2$ & Foliated nodule & 13.2 & 17.55 & -4.35 & 81.54 & 81.76 & +22 \\
\hline \multicolumn{8}{|c|}{ 201-1230A- } \\
\hline $15 \mathrm{H}-5$ & Fizzing sediment & 17 & 19.48 & -2.48 & 123.47 & 123.37 & -10 \\
\hline $18 \mathrm{H}-3$ & Fizzing sediment & 15.4 & 19.73 & -4.33 & 141.8 & 141.9 & +10 \\
\hline $19 \mathrm{H}-1$ & Nodule & 16.6 & 22.08 & -5.48 & 148.3 & 148.57 & +27 \\
\hline \multirow[t]{2}{*}{$26 \mathrm{H}-2$} & Fizzing sediment & 15.5 & 19.01 & -3.51 & 199.91 & 199.58 & -33 \\
\hline & & & Average: & -4.03 & & & \\
\hline
\end{tabular}

Notes: ${ }^{*}=$ core liner temperature measured at the location of hydrate or fizzing sediment. $\dagger$ $=$ average temperature of the core liner adjacent to the hydrate-bearing or fizzing sediment interval. $I R=$ infrared. 
K.H. FORD ET AL.

ChAPTER 4, INFRARED Thermal IMAGING

Table T2. Average and standard deviation of core liner temperatures.

\begin{tabular}{|c|c|c|c|}
\hline Core & $\begin{array}{l}\text { Core top } \\
\text { depth } \\
\text { (mbsf) }\end{array}$ & $\begin{array}{l}\text { Average } \\
\text { core temp } \\
\left({ }^{\circ} \mathrm{C}\right)^{\star}\end{array}$ & $\begin{array}{c}\text { Standard } \\
\text { deviation } \\
\left({ }^{\circ} \mathrm{C}\right)\end{array}$ \\
\hline \multicolumn{4}{|c|}{ 201-1226B- } \\
\hline $1 \mathrm{H}$ & 0.0 & 19.76 & 0.51 \\
\hline $4 \mathrm{H}$ & 23.4 & 16.37 & 0.69 \\
\hline $5 \mathrm{H}$ & 32.9 & 18.02 & 0.48 \\
\hline $6 \mathrm{H}$ & 42.4 & 13.80 & 0.80 \\
\hline $7 \mathrm{H}$ & 51.9 & 18.13 & 0.52 \\
\hline $8 \mathrm{H}$ & 61.4 & 16.97 & 0.75 \\
\hline $9 \mathrm{H}$ & 70.9 & 17.42 & 0.69 \\
\hline $11 \mathrm{H}$ & 89.9 & 20.51 & 0.17 \\
\hline $12 \mathrm{H}$ & 99.4 & 17.08 & 0.92 \\
\hline $13 \mathrm{H}$ & 108.9 & 18.93 & 0.31 \\
\hline $15 \mathrm{H}$ & 127.9 & 19.28 & 0.28 \\
\hline $16 \mathrm{H}$ & 137.4 & 17.26 & 0.39 \\
\hline $17 \mathrm{H}$ & 146.9 & 18.53 & 0.30 \\
\hline $18 \mathrm{H}$ & 156.4 & 18.01 & 0.21 \\
\hline $19 \mathrm{H}$ & 165.9 & 18.89 & 0.56 \\
\hline $20 \mathrm{H}$ & 175.4 & 18.93 & 0.64 \\
\hline $21 \mathrm{H}$ & 184.9 & 18.67 & 0.86 \\
\hline $22 \mathrm{H}$ & 194.4 & 19.38 & 0.32 \\
\hline $23 \mathrm{H}$ & 203.9 & 19.69 & 0.30 \\
\hline $24 \mathrm{H}$ & 213.4 & 19.64 & 0.25 \\
\hline $25 \mathrm{H}$ & 222.9 & 18.76 & 0.29 \\
\hline $26 \mathrm{H}$ & 232.4 & 18.27 & 0.61 \\
\hline $27 \mathrm{H}$ & 242.4 & 19.99 & 0.85 \\
\hline $30 x$ & 271.9 & 18.64 & 0.34 \\
\hline $31 x$ & 281.5 & 19.52 & 0.35 \\
\hline $32 x$ & 290.8 & 18.35 & 0.59 \\
\hline $33 x$ & 300.5 & 17.31 & 0.39 \\
\hline $34 x$ & 310.2 & 17.82 & 0.96 \\
\hline $35 x$ & 319.8 & 18.24 & 0.28 \\
\hline $36 x$ & 329.4 & 17.05 & 0.24 \\
\hline $37 x$ & 339.0 & 19.16 & 0.29 \\
\hline $38 x$ & 348.7 & 18.44 & 0.52 \\
\hline $39 x$ & 358.4 & 16.41 & 0.66 \\
\hline $40 x$ & 368.1 & 17.78 & 0.55 \\
\hline $41 x$ & 371.1 & 17.94 & 0.43 \\
\hline $43 x$ & 380.0 & 21.95 & 0.85 \\
\hline $45 x$ & 397.2 & 19.84 & 0.92 \\
\hline $46 x$ & 406.8 & 18.92 & 0.74 \\
\hline $47 x$ & 416.4 & 19.47 & 0.61 \\
\hline \multicolumn{4}{|c|}{ 201-1230A- } \\
\hline $1 \mathrm{H}$ & 0.0 & 16.91 & 0.38 \\
\hline $5 \mathrm{H}$ & 33.3 & 18.59 & 0.46 \\
\hline
\end{tabular}

\begin{tabular}{|c|c|c|c|}
\hline Core & $\begin{array}{c}\text { Core top } \\
\text { depth } \\
\text { (mbsf) }\end{array}$ & $\begin{array}{l}\text { Average } \\
\text { core temp } \\
\left({ }^{\circ} \mathrm{C}\right)^{*}\end{array}$ & $\begin{array}{c}\text { Standard } \\
\text { deviation } \\
\left({ }^{\circ} \mathrm{C}\right)\end{array}$ \\
\hline $\begin{array}{c}201-123 \\
6 \mathrm{H}\end{array}$ & 33.5 & 18.02 & 0.36 \\
\hline $\begin{array}{c}201-123 \\
6 \mathrm{H}\end{array}$ & 42.8 & 16.91 & 0.38 \\
\hline $\begin{array}{c}201-123 \\
7 \mathrm{H} \\
8 \mathrm{H}\end{array}$ & $\begin{array}{l}43.0 \\
52.5\end{array}$ & $\begin{array}{l}20.17 \\
18.85\end{array}$ & $\begin{array}{l}0.53 \\
0.28\end{array}$ \\
\hline $\begin{array}{l}201-123 \\
8 \mathrm{H} \\
9 \mathrm{H} \\
10 \mathrm{H}\end{array}$ & $\begin{array}{l}54.3 \\
60.8 \\
70.3\end{array}$ & $\begin{array}{l}19.70 \\
18.10 \\
19.82\end{array}$ & $\begin{array}{l}0.47 \\
0.31 \\
1.54\end{array}$ \\
\hline $\begin{array}{c}201-123 \\
11 \mathrm{H}\end{array}$ & 73.5 & 16.03 & 0.88 \\
\hline $\begin{array}{c}201-123 \\
11 \mathrm{H}\end{array}$ & 79.8 & 17.30 & 1.24 \\
\hline $\begin{array}{c}201-123 \\
12 \mathrm{H}\end{array}$ & 81.0 & 15.64 & $1.12^{\dagger}$ \\
\hline $\begin{array}{c}201-123 \\
12 \mathrm{H}\end{array}$ & 89.3 & 18.60 & 0.96 \\
\hline $\begin{array}{c}201-123 \\
13 \mathrm{H}\end{array}$ & 90.5 & 20.72 & 0.99 \\
\hline $201-123$ & & & \\
\hline $\begin{array}{l}13 \mathrm{H} \\
14 \mathrm{H}\end{array}$ & $\begin{array}{r}98.8 \\
108.3\end{array}$ & $\begin{array}{l}18.28 \\
18.07\end{array}$ & $\begin{array}{l}0.68 \\
0.62\end{array}$ \\
\hline $15 \mathrm{H}$ & 117.8 & 18.59 & $0.84^{\ddagger}$ \\
\hline $17 \mathrm{H}$ & 129.3 & 17.42 & 0.37 \\
\hline $18 \mathrm{H}$ & 138.8 & 19.01 & $0.97 \ddagger$ \\
\hline $19 \mathrm{H}$ & 148.3 & 20.59 & $2.05^{\dagger}$ \\
\hline $21 \mathrm{H}$ & 158.8 & 18.42 & 1.56 \\
\hline $22 \mathrm{H}$ & 168.3 & 20.05 & 0.35 \\
\hline $26 \mathrm{H}$ & 198.8 & 18.35 & $0.82^{\ddagger}$ \\
\hline $27 \mathrm{H}$ & 206.3 & 19.19 & 0.43 \\
\hline $31 x$ & 229.6 & 18.20 & 0.41 \\
\hline $35 x$ & 245.0 & 18.57 & 1.27 \\
\hline $38 \mathrm{X}$ & 267.2 & 17.76 & 0.44 \\
\hline
\end{tabular}

Notes: * $=-200$ images along the length of each core were analyzed for minimum temperatures. The image minimum temperatures were then averaged. $\dagger=$ hydrate observed. $\ddagger=$ fizzing sediment (disseminated hydrate inferred). 